\title{
Factors that Influence Attitudes of Computer Science Students towards Mathematics and Related Courses at the Tertiary Level of Education
}

\author{
Rosemary Twum \\ Department of Mathematics and ICT Education \\ University of Cape Coast \\ Cape Coast, Ghana
}

\author{
Christopher Yarkwah \\ Department of Mathematics and ICT Education \\ University of Cape Coast \\ Cape Coast, Ghana
}

\author{
**Benjamin Eduafo Arthur \\ College of Distance Education \\ University of Cape Coast \\ Cape Coast, Ghana
}

\begin{abstract}
The main purpose of this study was to examine the factors that influence the attitudes of computer science students towards the teaching and learning of mathematics and related courses in a public university situated in the Cape Coast Metropolis of Ghana. To achieve this, a descriptive survey design was adopted. In addition, a quantitative approach to data collection and analysis was employed for the study. The target population for the study were all Bachelor of Education (Computer Science) and Bachelor of Science (Computer Science) students in the said university. In all, 150 students were randomly sampled and used as the respondents for the study. The main instrument used for data collection process was a structured questionnaire. The study found that instructor or lecturer-student relationship have an influence on the students' attitudes towards the teaching and learning of mathematics and related courses. Also, the mathematics curricula used at the university have influence on students' attitude towards the teaching and learning of mathematics and related courses. In addition, institutional factors such as time allocation on time table and the adequacy of teaching and learning resources has some form of influence on students' attitude. Implications of the findings are further discussed in the study.
\end{abstract}

Keywords:- Factors, Attitude, Computer Science, Mathematics.

\section{INTRODUCTION}

Mathematics is an essential foundation necessary in order to study computer science (Beaubouef, 2002). Computer science students obviously need to use mathematics because it encourages logical reasoning, critical thinking, abstract thinking, problem-solving as well as creativity which has a positive effect on their learning of their courses in Computer Science. This means that those majoring in Computer Science and Computer Science related programmes are required to have a deeper knowledge in mathematics for them to become successful in their computer science career. The reason being that a strong background knowledge in mathematics is not only important in learning how to code mathematics expressions in a programming language, or in converting to and from hexadecimal or binary number systems but also needful at the advanced level in the computer science programme (Beaubouef, 2002). Mathematics is embedded in most computer science courses. Even research has revealed that having a strong mathematical understanding is significant to computer science education. "...mathematics is a mindset that fundamentally improves one's ability to devise and implement algorithms. Mathematics is used to model the problem domain, to specify and design high quality software, develop correct and efficient algorithms" (Paulson, 2002). Weaknesses in mathematical knowledge may hinder students' achievement in computer science courses.

Even though, mathematics is one of the necessary courses most students must take in order to major in various programmes from tertiary institutions, mathematics is seen as huge hurdle to cross instead of an appreciated learning experience (Ali, Ali \& Farag, 2014). Attitude significantly affects learning (Fadali, Valasquez \& Robinsoon, 2004). Attitudes cannot be observed directly but seen to be defined in numerous ways. Kislenko, Grevholm, and Lepik (2007), defined attitude as "thoughts, feelings, and behaviours". Another researcher, Kutto (2012) states that attitude is central to the education process and either promote or inhibits behaviour, influences choices to attend, respond value, participate or make commitment to educational activities. Attitudes of computer science students towards mathematics plays an important role in the teaching and learning processes of computer science and its effects on students' achievement in mathematics. In mathematics education, Tezer and Karasel (2010) assert that generally the relationship between students' attitude towards mathematics and their achievement in mathematics has been established that attitude towards mathematics influences achievement in mathematics.

Paulson (2002) studied how effective a strong mathematical background is in terms of learning and understanding academic courses in computer science.. The 
research revealed that " $19.6 \%$ of students had a decrease of two letter grades" and " $41.3 \%$ of students had a decrease of one letter grades" than their average grade in other computer science courses because of ineffective teaching in mathematics. Baldwin and Henderson (2002) and Henderson (2003) strongly argued that mathematics is important in software engineering and its practitioners. According to Henderson (2003), he argued that mathematics and computer science principles need to be applied to software engineering. Henderson (2003) continues to argue that "Mathematics is requisite for modelling software systems" and "Mathematical reasoning about software system is essential". A software developer is likely not to use mathematics explicitly, but they would use mathematics implicitly. In contrast, a computer scientist need to use mathematics explicitly. To become a successful computer science student he/she must have greater insight particularly in areas such as discrete mathematics, data structures, as well as algorithm analysis. Discrete Mathematics or Discrete Structure is generally taught by computer science faculties in certain universities and University of Cape Coast is no exception. At the University of Cape Coast, which is the study area for this research, Discrete Mathematics is taught by the Department of Mathematics and Data Structures \& Algorithms course is taught in the Computer Science department. All students offering computer science as a major must complete these two courses to earn their bachelor's degrees at the university.

Literature had it that factors that are associated with the lecturer that influences students' attitude are the teaching resources used by lecturer, lecturers' classroom management, lecturers' content knowledge and personality as well as topics that are taught with examples or real life experiences, (Yilmaz, Altun \& Olkun, 2010; Hodjes \& Kim, 2013; Marchis, 2011), teaching methods (Papanastasiou, 2000; Anghileri, 2006) and lecturers' attitude towards mathematics (Mensah, Okyere, \& Kuranchie, 2013; Zan \& Martino, 2007).

The nature of the classroom environment makes a difference in how students learn and achieve their goals. It was presented in a study that learning outcomes and students' attitudes toward learning were closely associated with the classroom environment (Entwistle and Entwistle 1991, 2003). Tailab (2013) reported that students in AlGharbi University found courses difficult because of nonavailability of modern textbooks and access to functional library. This presupposes that appropriate learning resources for mathematics and also equal access to these resources by all students are necessary.

At the department of Computer Education and Instructional Technology (CEIT) in Turkey, most courses requires substantial mathematics content knowledge. However, in a research, conducted with final-year students and graduates, most students viewed that mathematics courses were the least useful courses (Acat, Kılıç, Girmen $\&$ Anagün, 2007). The study concluded that undergraduate computer science education students who had more strong proficiency in mathematical knowledge had a better chance of being successful at the CEIT department (Acat et al., 2007). This gives the researchers the very enthusiasm to research about this study. A concrete attempt shall be made in this study to examine the factors that influence attitudes of computer science and computer science education students towards mathematics at the tertiary level of education. A critical investigation of the subjects is therefore necessary and crucial in an era where many innovations are taking place in the educational system of Ghana.

\section{$>$ Statement of the Problem}

Attitudes that are positive formed by a student when learning mathematics tend to remain with them for a long time and these attitudes are likely to help him/her become more proficient in mathematics (Evans, 1965). Therefore, lecturers must make sure not to create phobias amongst their students otherwise they would develop negative attitudes towards mathematics which could affect their success in Computer Science. There are a lot of computer science students who are not able to apply concepts and skills in mathematics that they learnt during their study. The difficulties of students to understand the basic concepts could eventually affect mathematical learning as well as computer science courses. The lack of understanding of basic mathematical principles can result in the inability to successfully study numerous subjects such as chemistry, engineering, and other important scientific disciplines like computer science (Yoseph, 1997). Some studies ( See for example; Acat et al., 2007; Tailab, 2013) have been conducted around the globe about the attitudes of computer science students towards mathematics, nonetheless, there is limited literature on the phenomenon in Ghana. This study attempts to unravel the factors that influence the attitudes towards learning of mathematics among computer science students in one public university in Ghana.

\section{$>$ Purpose of the Study}

Given the numerous role knowledge in mathematics play in other fields of study and the relevance of mathematics to computer scientist, the primary purpose of this study was to explore the factors that influence attitudes of computer science students towards mathematics at the tertiary level of education, specifically in one public university in Ghana.

\section{$>$ Research Questions}

The study was guided by the following research questions:

- What instructor related factors influence computer science students' attitude towards the teaching and learning of mathematics at the tertiary level of education?

- What curricular related factors influence computer science students' attitude towards mathematics at the tertiary level of education?

- What institutional related factors influence computer science students' attitude towards the teaching and learning mathematics at the tertiary level of education? 


\section{$>$ Design and Instrumentation}

A descriptive survey design was adopted to carry out the study in the University of Cape Coast. Descriptive survey design was used because it provides a more accurate picture of events and seeks to explain people's perception and behaviour on the basis on the data gathered at a point in time (Gay, 1992; Frankel \&Wallen, 2000). According to Frankel \& Wallen (2000), one great advantage of survey research is that it has the potential to provide us sufficient and relevant information that is obtained from quite a large sample of individuals. The main idea behind using this type of research is to better define an opinion, attitude or behaviour held by a group of people on a given subject. Data for the study was collected through the use of questionnaire. Singh (2007) retains that a questionnaire is almost always self-administered which allows respondents to fill them out themselves. The questionnaire was developed based on the research questions that were formulated to guide the study. In this study, the questionnaire that was used by the researchers comprised four sections. Section "A" covered demographics with only two items, section " $\mathrm{B}$ " had eight items that was designed to find out the teacher factors that influence students' attitudes towards mathematics, section "C" had five items about the institutional factors that influence students' attitudes towards mathematics, the last section which is section " $\mathrm{D}$ " also had five items under the research question "what curriculum factors influence students' attitude towards Mathematics?". The questionnaire had a total of twenty closed-ended items.

\section{$>$ Selection of Participants}

The population for this study included all B.Ed. Computer science and B.Sc. Computer science students in one public university in Ghana. A total of 240 computer science and computer science education students served as the target population for the study. The sample size for the study was 150 students using Krejcie and Morgan (1970) sampling table. According to Krejcie and Morgan (1970) sampling table, the correspondent sample size for a population more than or equal to 240 but less than 450 is 196. Simple random sampling was adopted in reaching out to the respondents to the study.

\section{Data Collection Procedure}

In research, it is the dream of researchers to have high response rate. As a result, names of students who participated in the study were not recorded on the instrument. Also, an initial visit was paid to the students in the various programmes during lectures to explain to the students the purpose of the research and how it would eventually impact on their study. Audience was sought from heads of the departments involved as well as lecturers whose class were going to be used in the study. At the meeting, the purpose of the study, its duration, and potential benefits were explained to the heads and lecturers b as well as all other participants for their consent to participate in the study and also allow the study to take place in their respective departments and lectures. Also, at these meetings, decisions about dates and times for the administration of the instrument were taken.

In all, administration of the instruments lasted for three working days. Each session lasted for about thirty minutes. The instruments were administered to 150 computer science and computer science education students in the selected public university. The administered instruments were supervised by the researchers. The questionnaires were given to the students during lecture hours with permissions granted by the respective lecturers and retrieved within thirty minutes. The completed instruments were then collected from the students and analyzed based on the phenomenon.

\section{$>$ Data analysis and discussion}

With data analysis, the researchers used the software; Statistical Package Program for Social Sciences (SPSS) version 21.0 in the analysis of the data. The collected questionnaires were coded and entered into the SPSS data analysis software for analysis. To establish the assessment of factors influencing the attitudes toward mathematics by computer science and computer science education students, descriptive statistics such as frequencies and percentages were used to analyse the data obtained for the study. For easy interpretation of the results, "Strongly agree" and "Agree" were combined into "agree" while "Strongly disagree" and "Disagree" were combined into "disagree"

\section{RESULTS AND DISCUDDION}

Research Question One: What instructor related factors influence computer science students' attitude towards the teaching and learning of mathematics at the tertiary level of education?

The objective was to find out the instructor related factors that influences computer science and computer science education students' attitude towards the teaching and learning of mathematics at the tertiary level of education. To answer this research question, data from these tertiary students were used based on items 3-10 on the questionnaire. The responses of students are shown in Table 1. 
ISSN No:-2456-2165

\begin{tabular}{|c|c|c|c|c|}
\hline Statement & $\begin{array}{c}\text { Strongly } \\
\text { Agree } \\
\mathbf{F}(\%)\end{array}$ & $\begin{array}{c}\text { Agree } \\
\text { F (\%) }\end{array}$ & $\begin{array}{c}\text { Disagree } \\
\text { F (\%) }\end{array}$ & $\begin{array}{c}\text { Strongly } \\
\text { Disagree } \\
\text { F (\%) }\end{array}$ \\
\hline $\begin{array}{c}\text { The way mathematics instructors care about student's } \\
\text { feelings, positively affect students' attitude towards } \\
\text { mathematics }\end{array}$ & $43(28.7)$ & $72(48.0)$ & $27(18.0)$ & $8(5.3)$ \\
\hline $\begin{array}{c}\text { Instructors friendliness positively influence student's } \\
\text { attitudes towards mathematics }\end{array}$ & $56(37.3)$ & $68(45.3)$ & $22(14.7)$ & $4(2.7)$ \\
\hline $\begin{array}{c}\text { Computer science major students towards mathematics is } \\
\text { negatively affected when instructors pay attention to the } \\
\text { mathematics major students while lecturing }\end{array}$ & $63(42.0)$ & $59(39.3)$ & $20(13.3)$ & $8(5.3)$ \\
\hline $\begin{array}{c}\text { Instructors fair grading of students in mathematics; } \\
\text { positively affects students' attitude towards mathematics }\end{array}$ & $41(27.3)$ & $69(46.0)$ & $25(16.7)$ & $15(10.0)$ \\
\hline $\begin{array}{c}\text { Instructors comments on students when they do poor } \\
\text { work negatively affect students' attitude toward } \\
\text { mathematics }\end{array}$ & $68(45.3)$ & $52(34.7)$ & $23(15.3)$ & $7(4.7)$ \\
\hline $\begin{array}{c}\text { Instructors using varied methods in teaching positively } \\
\text { affect student's attitudes towards mathematics }\end{array}$ & $59(39.3)$ & $63(42.0)$ & $18(12.0)$ & $10(6.7)$ \\
\hline $\begin{array}{c}\text { The way instructors relate mathematics lessons to real } \\
\text { life situations positively affect students' attitude towards } \\
\text { mathematics }\end{array}$ & $63(42.0)$ & $60(40.0)$ & $16(10.7)$ & $11(7.3)$ \\
\hline $\begin{array}{c}\text { The way instructors show mastery of content and } \\
\text { confidence when teaching positively affect students' } \\
\text { attitude towards mathematics }\end{array}$ & $56(37.3)$ & $68(45.3)$ & $22(14.7)$ & $4(2.7)$ \\
\hline
\end{tabular}

Table 1:- Frequencies and Percentages on Instructor Related Factors That Affects Computer Science and Computer Science Education Students' Attitude towards Mathematics

A cursory look at Table 1 indicates that $82.6 \%$ of respondents generally agreed to the fact that lecturer's friendliness positively affects students' attitudes towards mathematics while $17.4 \%$ disagreed. This gives an impression that most students want quality, friendly yet respectful relationship with lecturers when giving instructions in the classroom. Mathematics lecturers and computer science and Computer Science Education students are not close to have a healthy relationship which could positively affect computer science students' attitude towards learning mathematics. Computer science students are afraid to approach a mathematics lecturer to seek for help when they are not doing well in the course. This tends to make most of the computer science students fail at the end of the semester. Also $81.0 \%$ of the respondents agreed that when lecturers pay much attention to the mathematics major students than the Bachelor of Education [B.Ed.] and Bachelor of Computer Science [B.Sc.] major students, this negatively affect B.Ed. and B.Sc. Computer Science students' attitude towards learning mathematics. This percentage imply that these category of students want to be treated equally and also want to be given a chance to take responsibility for their own learning and express themselves. Collaboration and equality can promote not only team work but also healthy competition and selfconfidence when paired with students from mathematics major whiles $18.6 \%$ of the respondents disagreed.
Again, $80.0 \%$ respondents generally agreed that lecturers' bad comments on students when they do poor work negatively affects their attitude towards mathematics while $20.0 \%$ respondents generally disagreed. This result is not surprising since students gets intimidated when being badly criticized for asking a question and also performing badly in a quiz or exams. This means that students want lecturers to understand, listen respectfully and acknowledge their point of view. Lecturers' act of giving criticism is to put students' right and make them achieve their goal but when it is to the extreme, students shy away from the teaching and learning of mathematics. Furthermore, $81.3 \%$ respondents agreed to it that lecturers using varied methods in teaching positively affects students' attitude towards mathematics and $18.7 \%$ disagreed to that fact. This study, however, confirms the importance of using varied methods of teaching, which as a matter of fact go a long way to catch the attention of the learner. Furthermore, $82.0 \%$ respondents agreed that when lecturers relate mathematics lessons to real life situations positively it affect students' attitude towards mathematics while $18.0 \%$ disagreed. There is a caution of course that students' misconception can interfere with new learning so this makes students understand that exposure to the application of content in real life situations may help to correct such misconceptions. Without relevance, important concepts may seem unnecessary. Students gets demotivated when they could 
not see how the theory is applicable to the discipline they are studying and in other fields of endeavour. This finding conforms to that of Papanastasiou, (2000) who revealed that teaching methods affect the attitudes of students towards the learning of mathematics. Similar to the finding above, Yilmaz et al., (2010) also found that teaching topics with real life enriched examples and teachers' content knowledge influence students' attitudes towards the study of mathematics.

Research Question Two: What curricula related factors influence computer science students' attitude towards mathematics at the tertiary level of education?
This research question sought to find out the plans for activities or subject contents, the materials that are to be used in presenting the contents, the ways in which the activities are to be conducted and the evaluation of the subject taught. Thus, the question posed was "What curricular related factors influence computer science students' attitude towards mathematics at the tertiary level of education?" To accomplish this, items 16-20 on questionnaire sought to elicit responses from the respondents. The responses of students are shown in Table 2.

\begin{tabular}{|c|c|c|c|c|}
\hline Statement & $\begin{array}{l}\text { Strongly } \\
\text { agree } \\
\text { F }(\%)\end{array}$ & $\begin{array}{l}\text { Agree } \\
\text { F (\%) }\end{array}$ & $\begin{array}{c}\text { Disagree } \\
\text { F }(\%)\end{array}$ & $\begin{array}{c}\text { Strongly } \\
\text { Disagree } \\
\text { F (\%) } \\
\end{array}$ \\
\hline $\begin{array}{l}\text { The mathematics curriculum used at the } \\
\text { university negatively affects students' attitude } \\
\text { towards mathematics }\end{array}$ & $50(33.3)$ & $68(45.3)$ & $26(17.3)$ & $6(4.0)$ \\
\hline $\begin{array}{l}\text { Students have a negative attitude in learning } \\
\text { mathematics when they are ignored in the } \\
\text { development of the mathematics curriculum }\end{array}$ & $52(26.7)$ & $33(35.3)$ & $39(20.7)$ & $26(17.3)$ \\
\hline $\begin{array}{c}\text { Mathematics curriculum covers the entire } \\
\text { theoretical and application of mathematics in } \\
\text { computer science hence affects students } \\
\text { attitudes positively }\end{array}$ & $37(24.7)$ & $85(56.7)$ & $17(11.3)$ & $11(7.3)$ \\
\hline $\begin{array}{l}\text { Teaching strategies stipulated in the } \\
\text { mathematics curriculum have a positive effect } \\
\text { on students' attitudes to mathematics }\end{array}$ & $47(31.3)$ & $69(46.0)$ & $20(13.3)$ & $14(9.3)$ \\
\hline $\begin{array}{l}\text { Clearly stated instructional objectives of the } \\
\text { mathematics curriculum positively affects } \\
\text { students' attitudes to mathematics }\end{array}$ & $77(51.3)$ & $48(32.0)$ & $19(12.7)$ & $6(4.0)$ \\
\hline
\end{tabular}

Table 2:- Curriculum Factors That Affect B.Ed. And B.Sc. Computer Science Students' Attitude towards Learning Mathematics.

In general, it can be observed that curricula related factors have impacts on students' academic work. Most of the respondents representing $78.6 \%$ responded that the mathematics curriculum used at the university negatively affect their attitude towards mathematics whereas $21.4 \%$ disagreed. From these expositions, very important teaching and learning issues arise. These are methods of teaching and learning, teaching-learning materials, lesson plans, timetable for teaching and lessons to be taught from all the subjects in the curriculum. Moreover, $81.4 \%$ respondents agreed that when curriculum covers the entire theoretical and application of the mathematics it positively affects their attitude towards mathematics whereas $18.6 \%$ disagreed. Also, most $77.3 \%$ of the respondents agreed that teaching strategies stipulated in the mathematics curriculum have a positive effect on students' attitudes to mathematics whereas $22.7 \%$ disagreed. Instructional strategies is supposed to show the approach that a teacher applies to attain their instructional objectives (NTCM, 2000). What students learn does not solely depend on what they are taught but also how they are taught, their development level, and their interests as well as experiences. It is important for teachers to place emphasis on instructional objectives and topics, the learning expectations, time allocation for particular topics, the kinds of tasks they pose. These are necessary and play a vital role in teaching (Thompson \& Usiskin, 2014). When the curriculum is acceptable it assists in effective teaching and learning in Mathematics. There should be more emphasis on clearer concepts in Mathematics and involve more activities for students.

Research Question Three: What institutional related factors influence computer science students' attitude towards the teaching and learning mathematics at the tertiary level of education?

This research question sought to find out how the institution contribute in influencing students' attitudes towards the teaching and learning of mathematics. Specifically, items $11-15$ on the questionnaire are the responses gathered from students in the computer science and computer science education departments and are presented in Table 3. 
ISSN No:-2456-2165

\begin{tabular}{|c|c|c|c|c|}
\hline Statement & $\begin{array}{c}\text { Strongly agree } \\
\text { F (\%) }\end{array}$ & $\begin{array}{c}\text { Agree } \\
\text { F (\%) }\end{array}$ & $\begin{array}{c}\text { Disagree } \\
\text { F (\%) }\end{array}$ & $\begin{array}{c}\text { Strongly Disagree } \\
\text { F (\%) }\end{array}$ \\
\hline $\begin{array}{c}\text { Mathematics lecture periods for computer } \\
\text { science students in the timetable negatively } \\
\text { affects students' attitude towards mathematics }\end{array}$ & $44(29.3)$ & $40(26.7)$ & $53(35.3)$ & $13(8.7)$ \\
\hline $\begin{array}{c}\text { Small mathematics class size affect students' } \\
\text { attitudes towards mathematics positively }\end{array}$ & $46(30.7)$ & $62(41.3)$ & $28(18.7)$ & $14(9.3)$ \\
\hline $\begin{array}{c}\text { Inadequate mathematics teaching and learning } \\
\text { resources in the school negatively affects } \\
\text { students' attitude towards mathematics }\end{array}$ & $77(51.3)$ & $48(32.0)$ & $19(12.7)$ & $6(4.0)$ \\
\hline $\begin{array}{c}\text { Mathematics classroom arrangement affects } \\
\text { students' attitudes towards mathematics } \\
\text { positively }\end{array}$ & $38(25.3)$ & $51(34.0)$ & $42(28.0)$ & $19(12.7)$ \\
\hline $\begin{array}{c}\text { Intimidations from other mathematics program } \\
\text { students affect computer science students } \\
\text { positively }\end{array}$ & $45(30.0)$ & $56(37.3)$ & $35(23.3)$ & $14(9.3)$ \\
\hline
\end{tabular}

Table 3:- Influence of institutional factors that affect B.Ed. and B.Sc. computer science students' attitude towards learning mathematics

Table 3 indicates that $56.0 \%$ respondents agreed to it that mathematics lecture periods for computer science students on the timetable negatively affects students' attitude towards mathematics whereas $44.0 \%$ disagreed. In view of this, respondents are not good with the lecture period, since lecture periods that last long makes them wander and tired of listening to instructions in the lecture theatre. This makes students less attentive during the long therefore affecting they are not able to get or understand the concepts discussed in class. Consequently, reduces them applying it to computer science courses.

Also, $72.0 \%$ respondents agreed that the small mathematics class size positively affects student's attitude towards mathematics whiles $28.0 \%$ disagreed. This gives an impression that students achieve better and great opportunity for individual interaction between teacher and student when the class size is small. Students, generally have better morale in a small class and less likely to feel overwhelmed by asking a question or giving a suggestion. Lecture halls for studying mathematics in the University of Cape Coast are large and they also combine many students from other programs in one lecture to study mathematics. This intimidates computer science students to ask questions or express themselves well when they do not understand the concepts. The large class size affects computer science students' attitude towards mathematics.

Again, $83.3 \%$ respondents agreed that inadequate mathematics teaching and learning resources in the school negatively affects students' attitude towards mathematics whereas $16.7 \%$ respondents disagreed. This percentage point to the fact that teaching learning materials significantly increase students' achievement by supporting students learning. It also adds important structure to lesson planning and delivery which helps students to understand the mathematics concept. The TLMS used to teach the mathematics course in the University of Cape Coast do not increase computer science students' achievement. The finding is in line with Entwistle and Entwistle, (2003) who discovered that students' attitudes toward learning were closely linked to the classroom environment. In agreement with the finding, Tailab (2013) who reported that students in Al-Gharbi University found mathematics courses difficult because modern textbooks and access to functional library materials are limited.

Implications of the research findings for teaching, learning and policy implementation

The findings from the study have several implications to both policy and practice since teacher factors, curriculum factors, and institutional factors all play a major role in determining the attitudes computer science and computer science education students develop towards the teaching and learning of mathematics. Lecturers should counsel and guide students with low performances on what to do to yield better grades and encourage or motivate students with weak performance so that they can make it with constant practice and not just criticize them. Another implication of the findings is that instructors should also show concrete examples and real life experiences through their teaching so that students would behold the relevance of the courses they do to their field of study, related areas and life in general to their computer science courses. There is the need for equal and fair treatment for both pure mathematics and computer science and computer science education students. Curricula used to teach students should be revised annually so as to meet the needs of the students and students should also be given an opportunity to give their input concerning the development of the curriculum. The institution should 
provide lecturers with adequate teaching and learning materials to aid their mathematics instruction.

\section{CONCLUSIONS AND RECOMMENDATIONS}

The major findings of the study revealed that lecturers, curriculum and the institution play key roles in shaping the attitude of computer science and computer science education students' attitude towards the teaching and learning of mathematics. It was revealed that lecture periods for these supposed students in the timetable negatively affects their attitude towards mathematics and therefore be looked at. Also, inadequate mathematics teaching and learning resources in the institution negatively affects students' attitude towards mathematics and therefore must be resourced with the needed teaching learning resources to address the challenges of the students. The study also concluded that, lecturers' negative comments to students when they perform poorly in mathematics negatively affect their attitude towards mathematics. Finally, the findings also revealed that mathematics curricula used at the university negatively affects students' attitude towards mathematics.

\section{REFERENCES}

[1]. Acat, M. B., Kılıç, A.K., Girmen, P. \& Anagün, Ş. S. (2007). The necessity and applicability levels of the courses that are offered in the departments of CEIT, The Turkish OnlinJournal of Educational Technology, 6(3), 120-128.

[2]. Ali, P. J., Ali, S. \& Farag, W. E. (2014). An Instrument to Measure Math Attitudes of Computer Science Students. International Journal of Information and Education Technology, 4(5), 459.

[3]. Anghileri, J. (2006). Scaffolding practices that enhance mathematics learning. Journal of Mathematics Teacher Education, 9(1), 33-52. http://eric.ed.gov/?id=EJ748803

[4]. Baldwin, D. \& Henderson, P. B. (2002). The Importance of Mathematics to the Software Practitioners. IEEE Software, March/April Issue, pp. 13.

[5]. Beaubouef, T. (2002). Why computer science students need math. ACM SIGCSE Bulletin, 34(4), 57-59.

[6]. Cater, G. S., \& Norwood, K. S. (1997). The relationship between teacher and students' belief about mathematics. School science and mathematics, 97(2), 62-67.

[7]. Entwistle, N. J. \& Entwistle, A. (1991). Contrasting forms of understanding for degree examination: the student experience and its implications. Higher Education, 22(3), 205 - 227

[8]. Entwistle, N., \& Entwistle, D. (2003).Preparing for examinations: the interplay of memorizing and understanding, and the development of knowledge objects.Higher Education Research and Development, 22, 19-41.

[9]. Evans, K.M (1965). Attitudes and Interest in Education. London: Routledge and Keg and Paul.
[10]. Fadali, M.S. Valasquez, N and Robinsoon, M (2004). Work in progress- is attitude toward mathematics a major obstacle to engineering education. 34th ASEE/IEEE Frontiers in Education Conference.

[11]. Frankel, J. R. \& Wallen, N. E. (2000). How to Design and Evaluate Research in Education. Boston: McGraw-Hill.

[12]. Gay, L. R. (1992). Educational Research: Competencies for Analysis and Application. New York: 4Merrill.

[13]. Greaney, V. (2006). Text-books, respect for diversity and social cohesion in Promoting social cohesion through education: Case studies and tools for using text books and curricular. Washington DC: World Bank.

[14]. Henderson, P. B. (2003). Mathematical Reasoning in Software Engineering Education. Communications of the ACM, 46(9), 45-50.

[15]. Hodges, C. B., \& Kim, C. (2013). Improving college students' attitudes toward mathematics. TechTrends, 57(4), 59-66. doi:10.1007/s11528-013-0679-4

[16]. Kislenko K. Grevholm B. and Lepik M. (2007). Mathematics is important but boring: Students' beliefs and attitudes towards mathematics. Norway: Tapir Academic Press, pp. 349-360.

[17]. Köğce, D., Yıldız, C., Aydın, M. \& Altındağ, R., (2009). Examining Elementary School Students' Attitudes towards Mathematics in Terms of Some Variables, Procedia Social and Behavioral Sciences, 1(1), 291-295.

[18]. Krejcie, R. V., \& Morgan, D. W. (1970). Determining sample size for research activities. Educational and psychological measurement, 30(3), 607-610.

[19]. Kutto, W. K. (2012). Effect of delegation of duties and responsibilities in management of primary schools in Kosirai division, Nandi North District, Kenya. Unpublished Doctoral dissertation, Mount Kenya University.

[20]. Marchis, I. (2011). Factors that influence secondary school students' attitude to mathematics, Procedia Social and Behavioural Sciences. 29, 786-793.

[21]. Mensah, J. K., Okyere, M., \& Kuranchie, A. (2013). Student attitude towards mathematics and performance: Does the teacher attitude matter? Journal of Education and Practice, 4(3), 132-139.

[22]. National Council of Teachers of Mathematics (2000). Principle and standards for school mathematics (NCTM): Reston.

[23]. Papanastasiou, C. (2000). Effects of attitudes and beliefs on mathematics achievement. Studies in Educational Evaluation, 26, 27-42.

[24]. Paulson, H.G. (2002). Computer science students need adequate mathematics background. Retrieved from http://www.math.uoc.gr/ ictm2/Proceedings/pap398.p df

[25]. Sileshi Z. (2005). Gender difference in mathematics Achievement as a function of attitude in grade 8 through 11. Unpublished Master thesis. Addis Ababa University. 
[26]. Singh, K. (2007). Quantitative social research methods. London Sage Publications.

[27]. Tailab, M. M. (2013). Difficulties of academic achievement in principles of accounting courses for the student perspective evidence from Libya, Higher Education Studies; 3(5); 36 - 46.

[28]. Tezer, M. \& Karasel, N. (2010). Attitudes of primary school 2nd and 3rd grade students towards mathematics course, Procedia Social and Behavioral Sciences, 2, p.5809.

[29]. Thompson, D. R., \& Usiskin, Z. (2014). Enacted mathematics curriculum: a conceptual framework and research needs. Charlotte, NC: IAP, Information Age Publishing, Inc.

[30]. Yilmaz, C., Altun, S. A. \& Ollkun, S. (2010). Factors affecting students' attitude towards math: ABC theory and its reflection on practice. Procedia Social Science and Behavioural Sciences, 2, 4502-4506.

[31]. Yoseph, S. (1997). The relationship between attitude and achievement in mathematics among boys" and girls" in grade 6, 7, and 8. The case of Arsi zone. Unpublished master thesis. Addis Ababa University.

[32]. Zan, R., \& Di Martino, P. (2007). Attitude towards mathematics: Overcoming the positive/negative dichotomy. The Montana Mathematics Enthusiast Monograph, 3, 157-168 